\title{
BMJ Global Health Health systems resilience and preparedness: critical displacements and disruption
}

\author{
Mickey Chopra, Toby Kasper
}

To cite: Chopra M, Kasper T. Health systems resilience and preparedness: critical displacements and disruption. BMJ Global Health 2021;6:e007237. doi:10.1136/ bmjgh-2021-007237

Handling editor Stephanie M Topp

Received 23 August 2021 Accepted 30 August 2021

Check for updates

(C) Author(s) (or their employer(s)) 2021. Re-use permitted under CC BY-NC. No commercial re-use. See rights and permissions. Published by BMJ.

World Bank Group, Washington, District of Columbia, USA

Correspondence to Dr Mickey Chopra; mchopra@worldbank.org

\section{INTRODUCTION}

COVID-19 has highlighted the importance of resilient health systems. The concept of resilience has been evolving, with attributes such as feedback loops, learning capacity, adaptable management, flexibility and openness to systemic change take on greater importance from the earlier emphasis upon more fixed attributes such as numbers of laboratories, surveillance systems, etc ${ }^{1-3}$

However, a recent review notes the missing role of power relations and actors in such studies. ${ }^{4}$ That this is so prevalent suggests a systematic oversight. Here, we identify three 'displacements' in many approaches to resilience and how this can radically change the approach.

\section{DISPLACEMENT OF POLITICAL ECONOMY}

In the face of perpetual and multiple threats, the emphasis is on the resourcefulness and ingenuities of individuals and communities that refuse to surrender to all forms of endangerment. This emphasis on resourcefulness and ingenuity is part of the wider assemblage of 'disaster management' that focuses on the importance of being prepared and resilient against shocks such as climate change and, now, pandemics. ${ }^{5}$

Earlier these shocks were understood to be an act of nature or divinity, whereas they are now understood to be the almost inevitable side effect of development and modern life. The corollary of this is that individuals and communities need to be guided through this complex world by technical experts, who can deploy scientific methods to dissect and understand problems. ${ }^{6}$ Subsequently, the focus is on the expert measurement of 'ontologies of vulnerability'-deficits in individuals, communities or systems. Prescriptions to 'fill' these deficits invariably focus on public-private partnerships, civil society and

\section{Summary}

The COVID-19 pandemic has presented an opportunity to reconsider health systems from the perspective of resilience and pandemic prevention and preparedness.

- Lessons from previous epidemics along with insights from other fields have not only already given rise to a burgeoning literature on elements of such systems but have also systematically underplayed key elements such as power.

- We argue that the current framing of the issues is displacing several more fundamental drivers of poor systems performance and population outcomes such as political economy, politics and history.

- The incorporation of a broader framing of the issues leads to a very different approach towards analysing the causes and formulating the response to build more resilient and just health systems.

individual efforts. ${ }^{7}$ The underlying political economy-the wider interaction of politics and the economy-is often left unexamined.

The latest manifestation of this impulse is the concept of 'one health'. This rightly highlights the interconnections between humans, animals and their shared environment but the focus on the pathogen, hosts and immediate environment displaces key political economy determinants such as global capital flows that increasing shape land ownership and use and agricultural practices. The rapidly changing rural landscapes and livelihoods, for example, even in the poorest periphery of the world, are now shaped by the investment decisions of global mining, agricultural, transport and retail industries and finance speculators made in a few global centres. ${ }^{8}$

\section{DISPLACEMENT OF POLITICS}

COVID-19, along with Ebola, HIV and avian influenza, is presented as a further sign of the universal, catastrophic power of external natural forces. Such a framing enables the 
displacement of the politics in at least three ways: First, there is no clear privileged subject for change, the enemy is often externalised and objectified. Requiring everyone to act equally against 'natural disasters' blurs both the political origins of causes (eg, uneven distribution of power relations, networks of control and influence) and those social groups or movements best placed to combat them. Second, the fact that all geographies and groups are affected enables a universalistic rhetoric to be deployed, but this obscures the fact that politics shapes who is most affected. This has been clearly illustrated by the very different impacts of COVID-19 on poorer, marginalised populations ${ }^{9}$ but where their specific experience and differential claims have often been subsumed by the "we are in it all together' discourse. ${ }^{10}$ Third, the impending catastrophes of future outbreaks lead to a sense that if we refrain from acting immediately, our world's future is in grave danger-the experts need to start acting without waiting for the messiness of regular politics. ${ }^{11}$

This fits well with the recent shift of global agencies away from often frustrated attempts to build state and institutional capacity towards governance approaches. Greater attention is now given to specific 'policies' rather than 'politics' and to 'populations' rather than collective political subjects such as 'citizens'. All bolstered by a reliance upon global experts to measure progress rather than engaging and strengthening local measurement and accountability systems. ${ }^{12}$

\section{DISPLACEMENT OF HISTORY}

The long history of the medical establishment's role in advancing racist, sexist and classist ideologies has received renewed attention as part of efforts to understand vaccine hesitancy. ${ }^{13}$ Particularly blatant examples such as the Tuskegee experiments on black men or the British military's testing of the effects of mustard gas on Indian soldiers are now widely acknowledged. But the narrow focus on a few egregious episodes contributes to burying other histories and with it a more radical understanding of the current situation.

One example is the genealogy of epidemiology and infection control tools (e.g., mapping, quarantining of contagion) and language (e.g., reconnaissance, invasion, combat) that were originally mobilised by colonial administrations to both control rebellion and obscure its own motives, agency and legitimacy. More recent analysis traces how these tropes have been reinvented and repurposed by different regimes up to the present day. ${ }^{14}{ }^{15}$ Dismissing local criticism of epidemiology and public health measures as 'unscientific' ignores the complicated histories that many marginalised groups have with these concepts. ${ }^{16}$

The historical shaping of current social relations by forces that are still dominant is another example. The main structural drivers of the differential impact of COVID-19 on marginalised rural populations in the American west, for example, were generated a century ago, when the US Congress rejected a proposal for a communitarian, decentralised, river-basin-confined settlement system for the region and instead supported large-scale corporate interests pursuing the construction of dams and other mega-water projects. ${ }^{17}$ This, in turn, relied on the formation of institutions such as large-scale agribusiness and an oppressed landless agrarian workforce (now largely made up of immigrants) for its perpetuation, ${ }^{18}$ groups that have suffered disproportionately from COVID-19. ${ }^{19}$

\section{DISPLACING THE DISPLACEMENTS}

Without addressing these displacements risks a health resilience and preparedness agenda with a veneer of progressiveness but which closes down more radical critiques by consolidating around expert, technocratic power, by generating a shrunken, non-conflictual critique of social power structures, and by focusing the scope of proposed solutions heavily on the individual. Counterintuitively, here we suggest two further displacements that could 'recentre' critical perspectives: displacing an ontology of vulnerability with an ontology of oppression and displacing the domination of experts with a greater plurality of knowledge and voices.

The pandemic reminds us that the processes for the persistence of inequities reside not only just in formal relationships but also in the everyday practices such as bureaucratic administration or workplace safety. Mapping, in specific settings, how the pandemic is reenforcing what Young calls the 'five faces of oppression'-exploitation of labour (workplace and living space), marginalisation of social groups by virtue of their identity, powerlessness (lack of resources to act meaningfully in political life), cultural imperialism and violence (including within the family) ${ }^{20}$-is one starting point for an approach that draws attention to the base structures and processes. ${ }^{21}$

This is one thread that can tie the technical with broader progressive social movements. Technical experts and agencies need to work with those most affected in a fully democratic process of understanding the structures and processes that have replicated and amplified different forms of oppression from 'up close, as internal to the collectivities and sensitive to human actions, to which they react swiftly' (Latour). ${ }^{22}$ A disruptive agenda-one that prevents shocks as much as dealing with them.

Sixty years ago a new US President made a call to arms to the post-war generation. Perhaps as a community of scientists, policy-makers and technocrats, we need to make a similar commitment and ask not what we can do to build back better from COVID-19 but rather ask what COVID-19 can do to amplify the voices, power and leadership of those that have lost the most.

Contributors Both authors conceptualised and wrote the article.

Funding The authors have not declared a specific grant for this research from any funding agency in the public, commercial or not-for-profit sectors. 
Competing interests None declared.

Patient consent for publication Not applicable.

Provenance and peer review Not commissioned; internally peer reviewed.

Open access This is an open access article distributed in accordance with the Creative Commons Attribution Non Commercial (CC BY-NC 4.0) license, which permits others to distribute, remix, adapt, build upon this work non-commercially, and license their derivative works on different terms, provided the original work is properly cited, appropriate credit is given, any changes made indicated, and the use is non-commercial. See: http://creativecommons.org/licenses/by-nc/4.0/.

\section{REFERENCES}

1 Turenne CP, Gautier L, Degroote S, et al. Conceptual analysis of health systems resilience: a scoping review. Soc Sci Med 2019;232:168-80.

2 Nuzzo JB, Meyer D, Snyder M, et al. What makes health systems resilient against infectious disease outbreaks and natural hazards? results from a scoping review. BMC Public Health 2019;19:1310.

3 Kruk ME, Ling EJ, Bitton A, et al. Building resilient health systems: a proposal for a resilience index. BMJ 2017;357:j2323.

4 Topp SM. Power and politics: the case for linking resilience to health system governance. BMJ Glob Health 2020;5:e002891.

5 Pugh J. Resilience, complexity and post-liberalism. Area 2014;46:313-9.

6 Giddens A. Modernity and Self-identity - Self and Society in the late Modern Age. Stanford USA: Stanford University Press, 1991.

7 Evans B, Reid J. Exhausted by resilience: response to the commentaries. Resilience 2015;3:154-9.
8 Wallace RG, Bergmann L, Kock R, et al. The dawn of structural one health: a new science tracking disease emergence along circuits of capital. Soc Sci Med 2015;129:68-77.

9 O'Dowd A. Covid-19: people in most deprived areas of England and Wales twice as likely to die. BMJ 2020;369:m2389.

10 Sobande F. 'We're all in this together': Commodified notions of connection, care and community in brand responses to COVID-19. Eur J Cult Stud 2020;23:1033-7.

11 Swyngedouw E. 'The Non-Political Politics of Climate Change. ACME 2013;12:1-8.

12 Adams V, ed. Metrics: What Counts in Global Health. Duke University Press, 2017.

13 Lin C, Tu P, Beitsch LM. Confidence and receptivity for COVID-19 vaccines: a rapid systematic review. Vaccines 2021;9:16.

14 Kolb AFR. Epidemic Empire: colonialism, contagion, and terror, 1817-2020. Chicago: University of Chicago Press, 2021.

15 Sriram V, Keshri VR, Kumbhar K. The impact of colonial-era policies on health workforce regulation in India: lessons for contemporary reform. Hum Resour Health 2021;19:100.

16 Richardson ET. On the coloniality of global public Heath. Med Anthropol 2018:6:101-18. doi:10.17157/mat.6.4.761

17 Stroshane T. Rivers of Empire: water, aridity, and the growth of the American West by Donald Worster. Berkeley Plan J 1988;3.

18 Harvey D. The nature of environment: the Dialectics of social and environmental change socialist register 1993;3.

19 Maxmen A. Inequality's deadly toll Nature, 2021. Available: https:// www.nature.com/articles/d41586-021-00943-x [Accessed 10 May 2021].

20 Young IM. Justice and the politics of difference. New Jersey: Princeton University Press, 1990.

21 Young IM. Responsibility for justice. Oxford: Oxford University Press, 2011.

22 Latour B. Down to earth: politics in the new climatic regime. Cambridge, UK: Polity press, 2018. 